\title{
A Multiobjective Optimal Design of a Hybrid Power Source System for a Railway Vehicle
}

\author{
Tomoyuki Ogawa Student Member (Waseda University) \\ Shinji Wakao Member (Waseda University) \\ Keiichiro Kondo Member (Railway Technical Research Institute)
}

Keywords: hybrid power source system, railway vehicle, multiobjective optimization, fuel cell, electric double layer capacitor

In this paper, we study an optimal design for a hybrid power source railway vehicle as an alternative to diesel railway vehicles. The hybrid power source railway vehicle is assumed to be composed of the fuel cell and the electric double layer capacitor. We apply the multiobjective optimization based on the genetic algorithm for the vehicle design, aiming at reduction of both initial cost and energy consumption. The pareto optimal solutions are obtained using the multiobjective optimization.

In this paper, we develop a simulation model of the hybrid power source railway vehicle and its electric power control methods. And we compose the multiobjective optimization problem as shown in Table 1 and 2. We obtain the pareto optimal solutions as shown in Table 3, Fig. 2 and Fig. 3. Finally, we categorize the pareto optimal solutions to some groups, which enables us to elucidate characteristics of the pareto optimal solutions. Consequently, using the

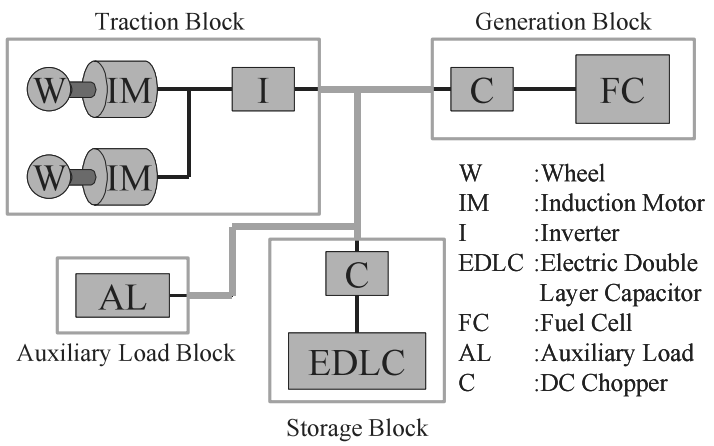

Fig. 1. Composition of a hybrid power source railway vehicle

Table 1. Design valuables for the optimization

\begin{tabular}{c|c|c|c}
\hline Design valuables & Minimum & Maximum & Bit \\
\hline \hline FC Power $P_{G \max }$ & $200[\mathrm{~kW}]$ & $515[\mathrm{~kW}]$ & 6 \\
\hline EDLC Capacity $C_{S}$ & $0.00[\mathrm{kWh}]$ & $15.75[\mathrm{kWh}]$ & 6 \\
\hline Threshold value $E_{2}$ & -2.00 & 13.75 & 6 \\
\hline Threshold value $E_{3}$ & 0.00 & 15.75 & 6 \\
\hline Threshold value $R_{2}$ & 0.000 & 0.875 & 3 \\
\hline Threshold value $R_{3}$ & 0.500 & 1.375 & 3 \\
\hline
\end{tabular}

Table 2. Objective functions for the optimization

\begin{tabular}{c|c}
\hline FC Power $P_{\text {Gmax }}$ & Minimize \\
\hline EDLC Capacity $C_{S}$ & Minimize \\
\hline FC generated energy $E_{G}$ & Minimize \\
\hline
\end{tabular}

multiobjective optimization approach we effectively comprehend the problem characteristics and can obtain the plural valuable solutions.

Table 3. Examples of pareto optimal solutions

\begin{tabular}{r|c|r|r|r|r|r}
\hline No. & Region & $P_{G \max }[\mathrm{kW}]$ & $C_{S}[\mathrm{kWh}]$ & $E_{G}[\mathrm{kWh}]$ & $M_{h}[\mathrm{t}]$ & $E_{C}[\mathrm{kWh}]$ \\
\hline \hline 1 & $(1)$ & 200 & 13.50 & 126.64 & 3.4 & 64.5 \\
\hline 2 & $(1)$ & 210 & 13.00 & 125.90 & 3.4 & 63.2 \\
\hline 3 & $(2-\mathrm{A})$ & 250 & 9.50 & 124.70 & 3.1 & 57.3 \\
\hline 4 & $(2-\mathrm{A})$ & 300 & 7.50 & 123.31 & 3.2 & 44.2 \\
\hline 5 & $(2-\mathrm{B})$ & 250 & 7.50 & 125.78 & 2.8 & 57.7 \\
\hline 6 & $(2-\mathrm{B})$ & 300 & 5.75 & 124.14 & 2.9 & 45.1 \\
\hline 7 & $(3)$ & 370 & 6.50 & 121.93 & 3.5 & 29.2 \\
\hline 8 & $(3)$ & 400 & 7.25 & 121.87 & 3.8 & 26.9 \\
\hline 9 & $(3)$ & 410 & 5.00 & 122.08 & 3.5 & 28.7 \\
\hline 10 & $(4-\mathrm{A})$ & 400 & 4.00 & 122.45 & 3.3 & 29.2 \\
\hline 11 & $(4-\mathrm{A})$ & 450 & 2.25 & 131.93 & 3.3 & 21.7 \\
\hline 12 & $(4-\mathrm{B})$ & 400 & 2.75 & 132.47 & 3.1 & 21.5 \\
\hline 13 & $(4-\mathrm{B})$ & 450 & 1.50 & 137.82 & 3.2 & 14.3 \\
\hline 14 & $(5)$ & 500 & 0.25 & 146.21 & 3.4 & 4.8 \\
\hline 15 & $(5)$ & 510 & 0.00 & 151.61 & 3.4 & 0.0 \\
\hline
\end{tabular}

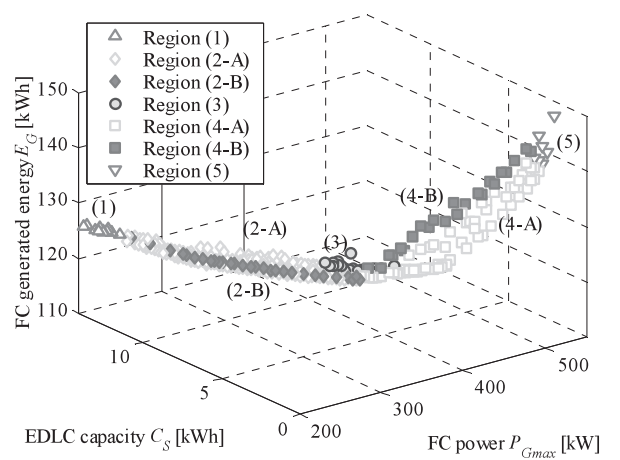

Fig. 2. A distribution of pareto optimal solutions

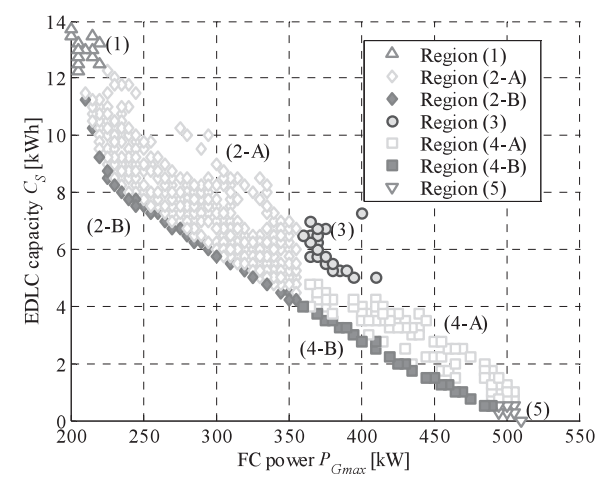

Fig. 3. Projections of a distribution of pareto optimal solutions 


\title{
鉄道車両への導入を想定したハイブリッド電源システムの 多目的最適化設計
}

\author{
学生員 小川 知行* 正 員 若尾 真治* \\ 正 員 近藤圭一郎**
}

\section{A Multiobjective Optimal Design of a Hybrid Power Source System for a Railway Vehicle}

Tomoyuki Ogawa*, Student Member, Shinji Wakao*, Member, Keiichiro Kondo**, Member

In this paper, we study an optimal design for a hybrid power source railway vehicle as an alternative to diesel railway vehicles. The hybrid power source railway vehicle is assumed to be composed of the fuel cell and the electric double layer capacitor. We apply the multiobjective optimization based on the genetic algorithm for the vehicle design, aiming at reduction of both initial cost and energy consumption. The pareto optimal solutions are obtained using the multiobjective optimization.

First we develop a simulation model of the hybrid power source railway vehicle and its electric power control methods. Next we derive the pareto optimal solutions as a result of the multiobjective optimization. Finally, we categorize the pareto optimal solutions to some groups, which enables us to elucidate characteristics of the pareto optimal solutions. Consequently, using the multiobjective optimization approach we effectively comprehend the problem characteristics and can obtain the plural valuable solutions.

キーワード : ハイブリッド電源システム, 鉄道車両, 多目的最適化, 燃料電池, 電気二重層キャパシタ

Keywords: hybrid power source system, railway vehicle, multiobjective optimization, fuel cell, electric double layer capacitor

\section{1. はじめに}

現在，鉄道の非電化区間では主にディーゼルエンジンを 動力源とする気動車が用いられている。ディーゼルエンジ ンはエネルギー変換効率の高さやこれまでの使用実績等か ら経済性の面で優れている。しかしながら, ディーゼルエ ンジンはその排出ガス中に有害物質を含み, かつ, 振動や 騒音が発生するといった短所も同時に有している。このよ うなディーゼル機関の鉄道車両駆動への適用に付随する問 題の一解決策として, 燃料電池 (FC) を動力源に用いると ともに, 電気二重層キャパシタ (EDLC) により回生電力 の活用を行うハイブリッド電源システムを有する鉄道車両 (以下，FC-EDLC ハイブリッド鉄道車両と略す）が検討さ れている。FC-EDLC ハイブリッド鉄道車両では以下のメ

\footnotetext{
* 早稲田大学大学院理工学研究科電気 - 情報生命専攻

干 169-8555 東京都新宿区大久保 3-4-1

Major in Electrical Engineering and Bioscience, Graduate School of Science and Engineering, Waseda University

3-4-1, Ohkubo, Shinjuku-ku, Tokyo 169-8555

** (財) 鉄道総合技術研究所

干 185-8540 国分寺市光町 2-8-38

Railway Technical Research Institute

2-8-38, Hikari-cho, Kokubunji 185-8540
}

リットが期待できる。

- 燃料電池のエネルギー変換効率の高さと回生電力活用 による運転エネルギーの削減

・蓄電装置を有するハイブリッドシステムのピークカッ 卜効果による発電装置の最大出力の低減

- 排出ガス中に含まれる二酸化炭素や窒素酸化物, 硫黄 酸化物および粒子状物質等の有害物質発生の解消

・エンジンの発生する振動・騒音解消による車内・車外 の快適性向上

このような背景のもと, 本研究では, 上記のような利点を 活かすべく, 適切なハイブリッド電源システム構築に関す る基礎的検討を行う。

従来の電気鉄道車両においては, 架線という単一の電源 からの電力供給を前提としており, 鉄道車両の電気機器設 計は確立した手法が存在している。しかしながら，ハイブ リッド電源システムにおいては, 発電装置と蓄電装置とい う2つの異なる電源により適切な電力分担を行う必要があ り, その制御法や機器容量の決定法については確立した手 法がまだ存在しない。この理由として, FC-EDLCハイブ リッド鉄道車両においては, 設計パラメータが多岐にわた り, システムの評価項目も数多く存在するため, これら全 てを同時に考慮して設計することが容易ではないことが挙 
ゲられる。

これまでに筆者らは，FC-EDLCハイブリッド鉄道車両 の効果的な運転において, 機器容量と電力制御法には密接 な関係があることを定量的に示しており ${ }^{(1)}$ ，両者を適切に 考慮して設計する必要があると考えられる。従って，本論 文では，燃料電池最大出力，キャパシタ容量，燃料電池発 電電力量を評価対象とし, 適切な機器容量と電力制御法を 同時に考慮して探索を行うハイブリッド電源システムの多 目的最適化設計法を提案する。

本論文では，始めに，発電装置として燃料電池を，蓄電 装置として電気二重層キャパシタを想定した FC-EDLC ハ イブリッド鉄道車両のシミュレーションモデルを構築する。 さらに, 最適化計算への適用を考慮して, SOC 重み関数と 車両エネルギー制御関数を新たに定義・導入した電力制御 法を提案する。提案手法を用いることで, 適切な電力制御 パターンを効果的に導出することが可能である。最後に, 多目的最適化計算の結果得られた多数のパレート最適解に 対し，その特性に応じた分類を行う。その結果, FC-EDLC ハイブリッド鉄道車両の設計方針の決定にあたり，提案手 法は, 多くの評価項目を同時に考慮しながら，これらを定量 的に明示できることが確認された。これにより，従来の電 気鉄道車両よりも探索空間が広範な FC-EDLC ハイブリッ ド鉄道車両の設計問題において，抽出できる情報量の多さ から提案手法が有用であると考えられる。

\section{2. シミュレーションモデルの構築}

〈2・1〉機器構成図 1 に示すような燃料電池とキャ パシタを用いたシリーズハイブリッドの機器構成を想定す る。駆動ブロックでは，インバータと誘導電動機を用いて 車両を駆動する。発電ブロックでは, 燃料電池により発電 し, チョッパにより電力変換を行う。蓄電ブロックでは, 電 気二重層キャパシタにより蓄電し, チョッパにより電力変 換を行う。車内負荷ブロックは，車内の照明・空調などの 負荷を想定する。

なお，本検討による最適化計算では，機器容量に関する 設計変数として燃料電池最大出力 $P_{G \max }$ とキャパシタ容量

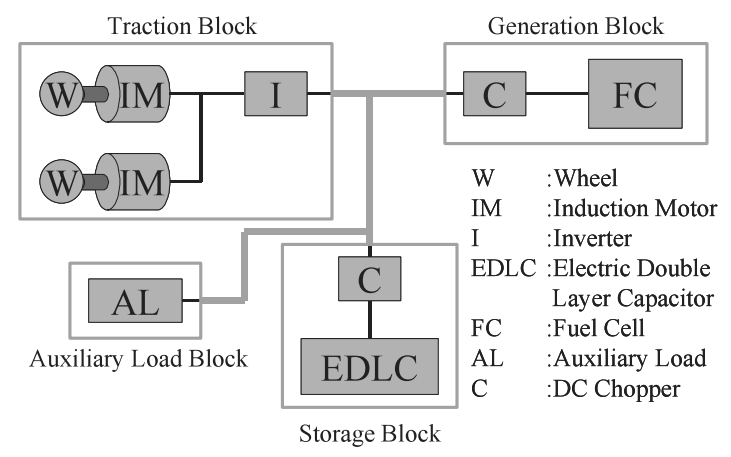

図 1 FC-EDLC ハイブリッド鉄道車両の構成

Fig. 1. Composition of a hybrid power source railway vehicle.
$C_{S}$ を設定する。それ以外の諸元に関しては表 1 を用いる。 また, 燃料電池の質量とキャパシタの質量の和をハイブリッ ド電源の質量 $M_{h}$ とし, これと列車基本質量 $M_{b}$ の和を列 車総質量 $M_{t}$ とする。

〈2·2〉 駆動ブロック＼cjkstart駆動ブロックでは，列車の電 動機や走行系を以下のような数式により模擬する (2)。電動 機制御はべクトル制御系を想定して, $\mathrm{dq}$ 軸上の固定子電流 指令值を決定し, それに応じた駆動電力や列車加速度を計 算する。

始めに, 電動機とインバータのモデルを構築する。定常 状態における固定子電圧は，次のように表される。

$$
\begin{aligned}
& v_{1 d}=R_{1} i_{1 d}-\omega_{s t} \sigma L_{1} i_{1 q} \\
& v_{1 q}=R_{1} i_{1 q}+\omega_{s t} L_{1} i_{1 d} .
\end{aligned}
$$

$v_{1 d}: \mathrm{d}$ 軸電圧 $[\mathrm{V}] \quad v_{1 q}: \mathrm{q}$ 軸電圧 $[\mathrm{V}]$

$i_{1 d}: \mathrm{d}$ 軸電流 $[\mathrm{A}] \quad i_{1 q}: \mathrm{q}$ 軸電流 $[\mathrm{A}]$

$\omega_{s t}:$ 電動機の固定子の角速度 $[\mathrm{rad} / \mathrm{s}]$

ただし，漏れ係数 $\sigma$ は，

$$
\sigma=1-\frac{M_{m}^{2}}{L_{1} L_{2}}
$$

である。駆動電力 $P_{T}[\mathrm{~kW}]$ は力行時には (4) 式を, 回生時 には(5) 式を用いて求める。

$$
P_{T}=\frac{N}{\eta_{i}} \frac{v_{1 d} i_{i d}+v_{1 q} i_{i q}}{1000} \ldots
$$

\begin{tabular}{|c|c|c|}
\hline \multirow{9}{*}{ Vehicle } & Number of cars $n$ & 2 [cars] \\
\hline & Base mass $M_{b}$ & $74.0[\mathrm{t}]$ \\
\hline & Gear ratio $G$ & 7.07 \\
\hline & Gear efficiency $\eta_{g}$ & 0.98 \\
\hline & Inverter efficiency $\eta_{i}$ & 0.975 \\
\hline & Wheel diameter $D$ & $0.82[\mathrm{~m}]$ \\
\hline & Inertia coefficient $C_{i}$ & 0.09 \\
\hline & Schedule deceleration $a_{b}$ & $2.2[\mathrm{~km} / \mathrm{h} / \mathrm{s}]$ \\
\hline & Number of motors $N$ & 4 \\
\hline \multirow{6}{*}{ IM } & Primary resistance $R_{1}$ & $0.186[\Omega]$ \\
\hline & Secondary resistance $R_{2}$ & $0.194[\Omega]$ \\
\hline & Primary inductance $L_{1}$ & $42.00[\mathrm{mH}]$ \\
\hline & Secondary inductance $L_{2}$ & $42.00[\mathrm{mH}]$ \\
\hline & Mutual inductance $M_{m}$ & $40.40[\mathrm{mH}]$ \\
\hline & Number of pole $P$ & 4 \\
\hline $\mathrm{FC}$ & Power density & $0.15[\mathrm{~kW} / \mathrm{kg}]$ \\
\hline \multirow{4}{*}{ EDLC } & Energy density & $6.5[\mathrm{Wh} / \mathrm{kg}]$ \\
\hline & Power density & $0.975[\mathrm{~kW} / \mathrm{kg}]$ \\
\hline & Internal resistance & $2.0[\Omega F]$ \\
\hline & Limit lower voltage & $50[\%]$ \\
\hline Chopper & Efficiency $\eta_{c h}$ & 0.95 \\
\hline $\mathrm{AL}$ & Load $P_{A}$ & $100[\mathrm{~kW}]$ \\
\hline
\end{tabular}

表 1 想定諸元

Table 1. An assumed specification. 


$$
P_{T}=N \eta_{i} \frac{v_{1 d} i_{i d}+v_{1 q} i_{i q}}{1000}
$$

次に, 列車の走行系のモデルを構築する。定常状態にお ける電動機 1 台あたりのトルク $\tau[\mathrm{Nm}]$ は,

$$
\tau=\frac{P}{2} \frac{M_{m}^{2}}{L_{2}} i_{1 d} i_{1 q}
$$

より算出する。車輪踏面での動輪周引張力 $T[\mathrm{kN}]$ は, 力行 時には (7) 式を, 回生時には (8) 式を用いて求める。

$$
\begin{aligned}
T & =\frac{2 G \tau N \eta_{g}}{1000 D} \\
T & =\frac{2 G \tau N}{1000 \eta_{g} D}
\end{aligned}
$$

また，単位質量あたりの走行抵抗 $R_{r}[\mathrm{~kg} / \mathrm{t}]$, 勾配抵抗 $R_{g}[\mathrm{~kg} / \mathrm{t}]$, 曲線抵抗 $R_{c}[\mathrm{~kg} / \mathrm{t}]$ は,

$$
R_{r}=1.32+0.0164 V+\left\{0.0280+0.0078(n-1) V^{2}\right\} / M_{t}
$$

$$
\begin{aligned}
& R_{g}= \pm n_{g} \\
& R_{c}=\frac{800}{r_{c}}
\end{aligned}
$$

$V:$ 速度 $[\mathrm{km} / \mathrm{h}] \quad M_{t}:$ 列車総質量 $[\mathrm{t}]$

$n_{g}$ : 勾配 [\%o] $\quad r_{c}$ : 曲線半径 $[\mathrm{m}]$

を用いて算出する (3)。これらより，列車抵抗 $R[\mathrm{kN}]$ は，

$$
R=\frac{\left(R_{r}+R_{g}+R_{c}\right) M_{t} g}{1000}
$$

$g:$ 重力加速度 $[\mathrm{m} / \mathrm{s} / \mathrm{s}]$

より求める。加速力 $f[\mathrm{~N} / \mathrm{kg}]$ は,

$$
f=\frac{T-R}{M_{t}}
$$

として表され, 慣性係数 $C_{i}$ を考慮して, 加速度 $a[\mathrm{~km} / \mathrm{h} / \mathrm{s}]$ は,

$$
f=\frac{1000}{3600}\left(1+C_{i}\right) a
$$

の関係より算出する。さらに, 加速度 $a[\mathrm{~km} / \mathrm{h} / \mathrm{s}]$ より列車の 速度 $V$ と位置を求める。また, 電動機の回転数 $n_{r p m}[\mathrm{rpm}]$ は,

$$
n_{r p m}=\frac{1000 G}{60 \pi D} V
$$

を用いて求める。電動機の電気角での回転角速度 $\omega_{r e}[\mathrm{rad} / \mathrm{s}]$, すべり角速度 $\omega_{s e}[\mathrm{rad} / \mathrm{s}]$, 固定子の角速度 $\omega_{s t}[\mathrm{rad} / \mathrm{s}]$ は,

$$
\begin{aligned}
& \omega_{r e}=2 \pi P \frac{n_{r p m}}{120} \\
& \omega_{s e}=\frac{R_{2}}{L_{2}} \frac{i_{1 q}}{i_{1 d}} \cdots \\
& \omega_{s t}=\omega_{r e}+\omega_{s e}
\end{aligned}
$$

より求める。 $\langle\mathbf{2} \cdot \mathbf{3}\rangle$ 発電ブロック＼cjkstart発電ブロックでは, 燃料電池 とチョッパを想定し検討を行う。本検討では, ピークカッ 卜効果を期待して ${ }^{(1)}$, 最適化の設計变数の 1 つである燃料 電池最大出力を抑えることを前提とする。このため, 燃料 電池最大出力は力行時の最大消費電力を上限として, 不足 する電力はキャパシタからの補助を用いることとする。

また, 燃料電池は, 極端に低い出力の場合を除いては, 効 率はほぼ一定になるものと考えられる。このため, 燃料電 池最大出力の $10[\%]$ 100 [\%] の範囲で効率がほぼ一定に なると考え, この範囲内で積極的に消費電力に追従させて 出力を変化させるものとする。

〈2·4〉蓄電ブロック＼cjkstart蓄電ブロックでは，電気二重 層キャパシタとチョッパを想定し検討を行う。キャパシタ 容量 $C_{S}$ は設計変数の 1 つであり, 表 1 のパワー密度と工 ネルギー密度を用いて, キャパシタ容量 $C_{S}$ の值から最大 充電電力 $P_{C \max }$ と最大放電電力 $P_{C \min }(<0)$ が決定される。 なお, 電気二重層キャパシタは, 最大電圧の $100[\%]$ から 50 [\%] までの範囲を使用するものとする。このため, 残存 容量は, 容量の 100 [\%] から 25 [\%]までの範囲を使用する。

$\langle\mathbf{2} \cdot \mathbf{5}\rangle$ 車内負荷ブロック 車内負荷ブロックは, 車 内の照明・空調などを想定する。夏期の負荷の大きい時期 を目安にして，一定の車内負荷電力 $P_{A}$ を想定する。

$\langle\mathbf{2} \cdot \mathbf{6}\rangle$ 引張力特性 本検討では, 図 2 のような力行 時の引張力特性を規定する。この引張力特性を満たすのに 必要な電力を, 燃料電池とキャパシタから供給する。たた し, 回生時には, キャパシタの最大充電電力 $P_{C \text { max }}$ を超え ない範囲で充電を行う。最大充電電力 $P_{C \text { max }}$ を超える場合 には，電流指令值を絞り込むことによって，回生電力を抑制 する。また, 後述する電力制御によりキャパシタの残存容 量を適正範囲に収めるべく制御を行うが，制御範囲を超え て満充電状態になった場合には回生を停止する。なお，回 生による減速力が, 計画減速度 $a_{b}$ に対して不足する場合に は，機械ブレーキを併用するものとする。

〈2.7〉対象路線 FC-EDLCハイブリッド鉄道車両の 適用を考慮すると, 比較的小さい機器容量のハイブリッド 電源によって走行が可能である路線が, 導入の可能性が高い

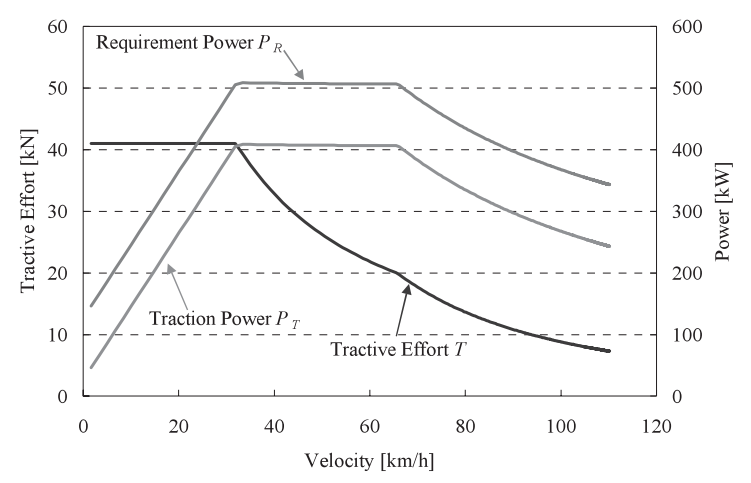

図 2 引張力特性

Fig. 2. Characteristics of the tractive effort. 


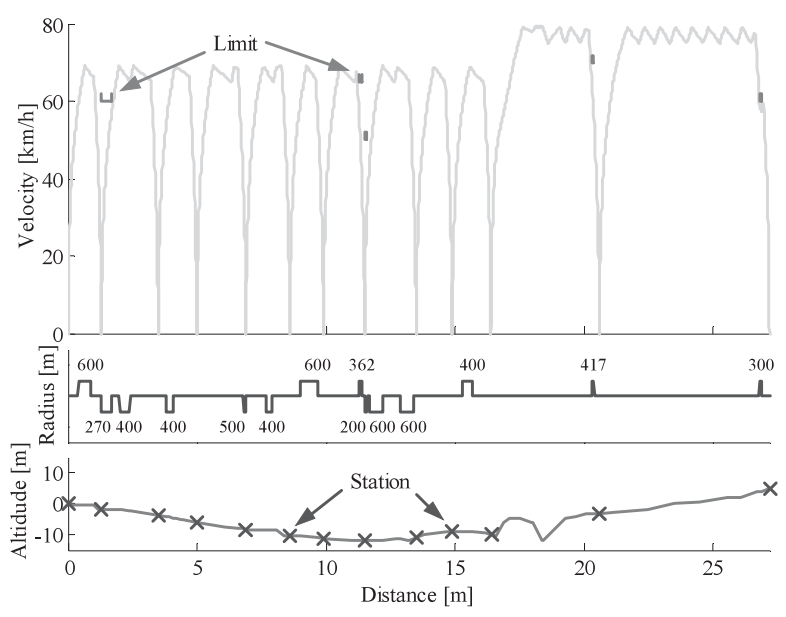

困 3 路線特性と運転曲線

Fig. 3. Characteristics of the line and the run curve.

と考えられる。このような路線の代表例として, 都市近郊 の平野部を通るような路線が考えられる。そこで，本論文 では, 図 3 に示す路線を解析対象として選定した。対象路 線は, 路線長 $27.2[\mathrm{~km}]$ の非電化路線であり, 典型的な都市 近郊の平野部を通る路線である。本路線は, 高低差 15 [m] 程度となっておりほぼ平坦である。駅数は全部で 13 駅あ り，始点に主要駅があり，終点付近を除いて比較的駅間が 短くなっている。本路線における運転曲線は図 3 を想定し た。なお，各駅の停車時間は $40[\mathrm{~s}]$ とした。この走行特性 を，設計時に満たすべき走行条件とした。

\section{3. 電力制御法の提案}

本論文では，ハイブリッド電源システムの多目的最適化 設計法に適した電力制御法を提案する。始めに，車両の工 ネルギーに注目した制御法を紹介する(4)。次に，この考え 方を基本として，機器容量の制約の下でキャパシタ残存容 量（SOC：State of Charge）が適切な範囲に収まるように, SOC 重み関数と車両エネルギー制御関数を新たに定義・導 入して具体的な制御法を提案する。

〈3・1〉 車両総エネルギーによる電力制御ＦC-EDLC ハイブリッド鉄道車両の電力制御は，蓄電エネルギーと運 動エネルギーの和を車両総エネルギー $E_{V}$ として，この值 を一定に保つように燃料電池の発電電力を操作する。損失 や勾配の影響が小さければ，回生エネルギーとして回収さ れるエネルギー分が，走行中に運動エネルギーとして保持 されているものとみなすことができる。このため，車両総 エネルギー $E_{V}$ を一定に保つことにより，キャパシタ残存 容量が良好な範囲内に収まるものと考えられる(4)。具体的 には，キャパシタが満充電で駅を出発し，次駅の出発まで に満充電に戻ることを目指して燃料電池の発電電力を操作 する。

〈3・2〉 システム内の電力の相互関係 電力制御法に ついて検討するために，FC-EDLCハイブリッド鉄道車両 における電力の相互関係について考察する。消費電力 $P_{R}$

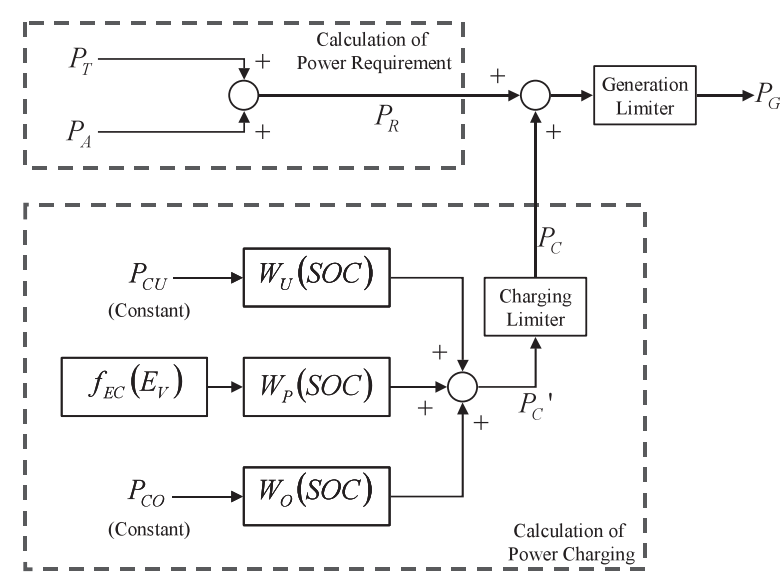

図 4 電力制御法の構成

Fig. 4. A diagram of the electric power control.

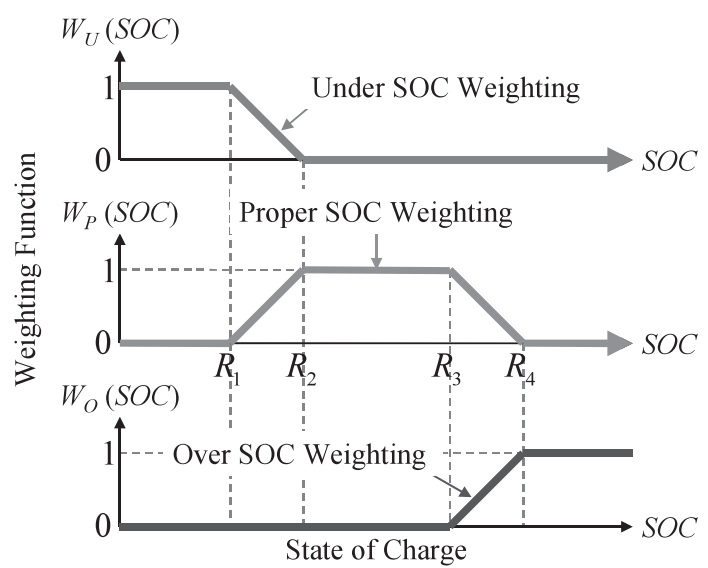

図 5 SOC 重み関数

Fig. 5. Weighting functions of the state of charge.

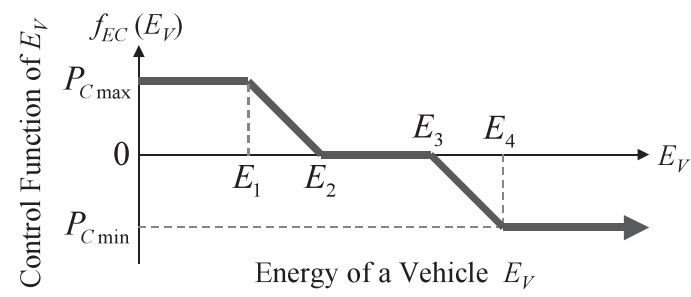

図 6 車両エネルギー制御関数

Fig. 6. Control functions of the energy of a vehicle.

は, 駆動電力 $P_{T}$ と車内負荷電力 $P_{A}$ の和として次式のよう に表される。ただし, 駆動電力 $P_{T}$ は, 回生時には負の值 となる。

$$
P_{R}=P_{T}+P_{A}
$$

また, 燃料電池の発電電力 $P_{G}$ は, キャパシタの充電電力 $P_{C}$ と消費電力 $P_{R}$ の和として次式のように考えられる。た だし, キャパシタの充電電力 $P_{C}$ は, 放電時には負の值と なる。

$$
P_{G}=P_{C}+P_{R}
$$


この関係より, 車両総エネルギーやキャパシタ残存容量を 制御する場合に, キャパシタの充電電力 $P_{C}$ を算出して, そ の值に基づき燃料電池の発電電力 $P_{G}$ の操作量を求める。

$\langle\mathbf{3} \cdot 3\rangle$ SOC 重み関数と車両エネルギー制御関数の導入 キャパシ夕の残存容量 SOC を適正な範囲に収めながら, 機器容量の縮小化や回生電力の有効な回収を目標として, 図 4 に示す電力制御法を提案する。ここで新たに，SOC 重 み関数と車両エネルギー制御関数 $f_{E C}\left(E_{V}\right)$ を図 5 , 図 6 に 示すように定義する。キャパシタの充電電力 $P_{C}{ }^{\prime}$ は以下の ように決定される。

$$
P_{C}{ }^{\prime}=W_{U}(S O C) P_{C U}+W_{P}(S O C) f_{E C}\left(E_{V}\right)+W_{O}(S O C) P_{C O}
$$

$W_{U}(S O C)+W_{P}(S O C)+W_{O}(S O C)=1$

$W_{U}(S O C): S O C$ 過小範囲の重み関数

$W_{P}(S O C): S O C$ 適正範囲の重み関数

$W_{O}(S O C): \mathrm{SOC}$ 過大範囲の重み関数

$P_{C U}: \mathrm{SOC}$ 過小範囲の充電電力

$P_{C O}: \mathrm{SOC}$ 過大範囲の充電電力

このように，SOC 重み関数により，SOC の值に応じて制 御方法が適切に切り替わる。具体的には, SOCが適正範囲 (制御間值： $R_{2} \sim R_{3}$ ) 内にある場合は，車両エネルギー制御 関数に基づいた制御が行われる。一方，SOC が適正範囲よ りも小さい場合や大きい場合には，SOCを適正範囲に戻す ための制御が新たに付加される。

$\mathrm{SOC}$ 重み関数の詳細は以下の通りである。SOC が小さ い場合は，SOCの下限值を下回ることを防止するという観 点から, SOC 過小範囲の重み関数 $W_{U}(S O C)$ により, 積極 的に充電が行われるようにする。今回の検討では, SOC 過 小範囲の充電電力 $P_{C U}$ は, 最大充電電力 $P_{C \text { max }}$ の值を設 定している。SOCが大きい場合は，満充電状態でのさらな る充電を防止するという観点から, SOC 過大範囲の重み関 数 $W_{O}(S O C)$ により, 充電を行わないようにする。従って, $\mathrm{SOC}$ 過大範囲の充電電力 $P_{C O}$ は, 0 以下の值を設定する。 今回の検討では, $S O C$ 適正範囲の重み関数 $W_{P}(S O C)$ によ $\eta$, 制御闇值 $R_{3} \sim R_{4}$ の範囲で十分に充電の絞り达みがで きると考え, $\mathrm{SOC}$ 過大範囲の充電電力 $P_{C O}$ は 0 を設定し ている。

一方, SOC が適正な範囲にあるときには, 車両エネルギー 制御関数に基づいた制御が行われる。車両エネルギー制御 関数 $f_{E C}\left(E_{V}\right)$ は, 車両総エネルギー $E_{V}$ が制御閾值 $E_{2}$ を下 回ると，以降の放電に備えた充電制御となる。また，制御 閾值 $E_{3}$ を上回ると, 力行時や㤢行時にキャパシタからの 積極的な放電を行って, 回生電力の有効な回収を狙った放 電制御となる。

以上のアルゴリズムにより, キャパシタの充電電力 $P_{C}$ （放電時には負となる）を求めるが，キャパシ夕の特性か ら, 最大充電電力 $P_{C \text { max }}$ と最大放電電力 $P_{C \text { min }}$ の制限があ るため, 充電電力 $P_{C}$ に次式のような充電電力リミッ夕を
設ける。

$$
P_{C}=\max \left(\min \left(P_{C}^{\prime}, P_{C \max }\right), P_{C \text { min }}\right)
$$

次に，キャパシ夕の充電電力 $P_{C}$ から，(20) 式をもとに燃 料電池の発電電力 $P_{G}^{\prime}$ を計算する。

$$
P_{G}^{\prime}=P_{C}+P_{R}
$$

さらに, 燃料電池の出力には, 最大出力 $P_{G \text { max }}$ と最小出力 $P_{G \text { min }}$ の制限があるため, 次式のような発電電力リミッ夕 を設ける。なお, 今回の検討では, 最小出力 $P_{G \text { min }}$ は最大 出力 $P_{G \max }$ の 10 [\%] の值としている。

$$
P_{G}=\max \left(\min \left(P_{G}^{\prime}, P_{G \max }\right), P_{G \min }\right)
$$

また，車両総エネルギー $E_{V}$ は，蓄電エネルギー $E_{S}$ と運動 エネルギー $E_{K}$ を用いることで次式のように考える。

$$
E_{V}=E_{S}+\eta_{r} \cdot \eta_{g} \cdot \eta_{m} \cdot \eta_{i} \cdot \eta_{c h} \cdot E_{K}
$$

すなわち，運動エネルギー $E_{K}$ として見达まれる回生エネ ルギーは，全てが回収できるわけではないので，(26) 式の ように回生見込久率 $\eta_{r}$ と歯車伝達効率 $\eta_{g}$ と電動機効率 $\eta_{m}$ とインバータ効率 $\eta_{i}$ と蓄電ブロックのチョッパ効率 $\eta_{c h}$ を 用いて損失を表現する。ここで，走行抵抗や機械ブレーキ による損失分や充放電損失を考慮して回生見込み率 $\eta_{r}$ は 0.75 , 電動機効率 $\eta_{m}$ は 0.92 と一定値を仮定している。な お，制御閾值 $E_{1} \sim E_{4}$ の值に関しては，駅停車中に満充電 となっている場合の車両総エネルギー $E_{V}$ を基準として規 格化する。

\section{4. 多目的最適化}

$\langle\mathbf{4} \cdot \mathbf{1}\rangle$ 多目的最適化の概要 多目的最適化の理論に おいて, 複数の目的関数間でのトレードオフをバランスさ せ得る解として, 以下に説明するパレート最適解が挙げら れている(5)。

多目的最適化問題は, 設計変数 $x$ (ベクトル)によって 表される $p$ 個の目的関数 $f_{k}(x) \quad(k=1, \ldots, p)$ を，制約条 件を満たす可能領域 $F$ において，なるべく小さくする問題 であると定義される。異なる設計変数 $x^{1}, x^{2}$ において,

$$
x^{1}, x^{2} \in F
$$

の条件下で, $p$ 個の目的関数 $f_{k}(x)$ に関して比較を行い,

$$
f_{k}\left(x^{1}\right) \leq f_{k}\left(x^{2}\right) \quad\left({ }^{\vee} k=1, \cdots, p\right) \cdots
$$

かつ,

$$
f_{k}\left(x^{1}\right)<f_{k}\left(x^{2}\right) \quad\left({ }^{\exists} k=1, \cdots, p\right)
$$

となるとき, $x^{1}$ は $x^{2}$ に優越するという。ある $x^{0}$ に優越する

$x \in F$

が存在しないとき， $x^{0}$ はパレート最適解であるという。

パレート最適解は解の集合として算出される。目的関数 が2つである場合のパレート最適解の例を図 7 に示す。図 7 において, 太線で示した原点寄りの境界部分がパレート最 適解となる。 


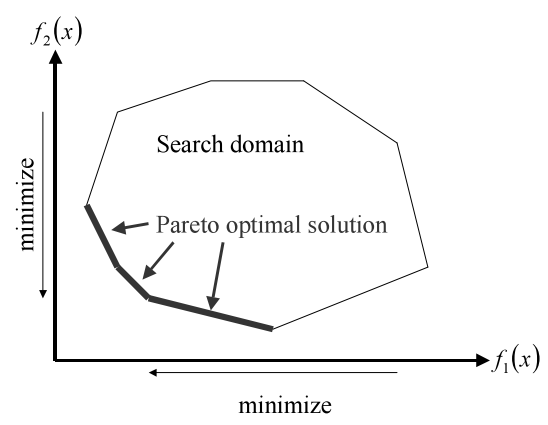

図 7 パレート最適解の概念

Fig. 7. Concept of pareto optimal solution.

表 2 設計変数一覧

Table 2. Design valuables for the optimization.

\begin{tabular}{c|c|c|c}
\hline Design valuables & Minimum & Maximum & Bit \\
\hline \hline FC power $P_{G m a x}$ & $200[\mathrm{~kW}]$ & $515[\mathrm{~kW}]$ & 6 \\
\hline EDLC capacity $C_{S}$ & $0.00[\mathrm{kWh}]$ & $15.75[\mathrm{kWh}]$ & 6 \\
\hline Threshold value $E_{2}$ & -2.00 & 13.75 & 6 \\
\hline Threshold value $E_{3}$ & 0.00 & 15.75 & 6 \\
\hline Threshold value $R_{2}$ & 0.000 & 0.875 & 3 \\
\hline Threshold value $R_{3}$ & 0.500 & 1.375 & 3 \\
\hline
\end{tabular}

表 3 目的関数一覧

Table 3. Objective functions for the optimization.

\begin{tabular}{c|c}
\hline FC power $P_{\text {Gmax }}$ & Minimize \\
\hline EDLC capacity $C_{S}$ & Minimize \\
\hline FC generated energy $E_{G}$ & Minimize \\
\hline
\end{tabular}

〈4・2 遺伝的アルゴリズムの採用 遺伝的アルゴリ ズムは，自然界における生物の進化モデルを模した最適化 手法である (6)。本論文では, 多点探索を行う遺伝的アルゴリ ズムの特徵を活かし，各目的関数を並列的に扱って計算を 行うことにより，複数の目的関数を同時に考慮してパレー 卜最適解を算出した。遺伝的アルゴリズムにおける各個体 の適応度算出は，ランキング法を用いた ${ }^{(5)}$ 。

$\langle\mathbf{4} \cdot \mathbf{3}\rangle$ 多目的最適化問題の設定 本検討では, 設計 変数 $x$ と目的関数 $f_{k}(x)$ は表 2 , 表 3 に示す通りとした。ま た，規定の運転曲線で運転する場合に，

・キャパシ夕残存容量が適正範囲を外れないこと

・必要な出力が不足せず得られること

を制約条件に設定した。この制約条件を満たした走行を実 現可能な解として扱った。実現可能な解の集合から, 設定 した目的関数に扔けるパレート最適解の探索が行われる。 目的関数は，車両の導入におけるイニシャルコストを抑え る観点から燃料電池最大出力 $P_{G \text { max }}$ とキャパシ夕容量 $C_{S}$ を最小化することを設定した。併せて，環境負荷やランニ ングコストを抑える観点から一回の走行に打ける燃料電池 発電電力量 $E_{G}$ を最小化することを設定した。

なお，電力制御法として 8 種類の制御間値を設定したが, これらが全て独立であると考えて，極度に広い設計空間で
最適化を行ったとしても, 有用な結果は得られないものと 考えられる。このため, 制御閾值を絞り达むこととして, 制御間値 $E_{1}, R_{1}$ は, 制御閾值 $E_{2}, R_{2}$ よりも 0.1 小さい值 を, 制御闇値 $E_{4}, R_{4}$ は, 制御間值 $E_{3}, R_{3}$ よりも 0.1 大き い值をそれぞれ設定した。

また，遺伝的アルゴリズムにおける個体数は 1024，世代 数は 4096 とした。複数の CPU を有する計算機を用いて計 算時間の短縮を図る目的で, 複数の設計変数に対する走行シ ミュレーションを同時に行う並列化処理を組み込んで計算 を行った。計算には, 4 個の CPU を有する計算機 (Opteron 280, Dual Core, Dual CPU, $2.4[\mathrm{GHz}]$ ）を使用し, 計算 時間は 2 時間 18 分であった。

$\langle\mathbf{4} \cdot \mathbf{4}\rangle$ パレート最適解の算出結果 最適化計算によ り得られたパレート最適解は 415 個であった。パレート最 適解の分布を図 8 に示す。また, 415 個のパレート最適解 の中から，代表的な点を抽出して表 4 に示す。今回設定し た最適化問題では，パレート最適解は多数生じる。このた め, システム設計に打ける有用な情報を抽出することを目 的として，パレート最適解に対して，それらの傾向に基づ いて, 7つの領域に分類して図表に示している。また, 図 8 の解釈を容易にするため, パレート最適解の分布を各平面 に射影して図 9 に示す。さらに, 1 回の走行におけるキャ パシタの総充電電力量 $E_{C}$ を図 10 に示す。

パレート最適解の概念から, 図 8, 図 9 では, 燃料電池最 大出力とキャパシ夕容量と燃料電池発電電力量のいずれに おいても優れない解は排除され, 設計上有用な解のみが抽 出されている。また, 表 4 に示したいずれのパレート最適 解に㧍いても, ハイブリッド電源の質量 $M_{h}$ は, 列車基本 質量 $M_{b} （ 74.0[\mathrm{t}]$ と想定）に比べて十分に小さく，質量の 観点に扔いてハイブリッド電源システムを車載することに は実用上問題はないものと考えられる。なお，ハイブリッ ド電源は車両床下に配置することを想定しており，普通列 車用の鉄道車両は床下に比較的余裕があるため, 体積の点 に拉いても問題ないものと考えられる。

図 9(a)より, 燃料電池最大出力 $P_{G \max }$ とキャパシ夕容 量 $C_{S}$ にはトレードオフ関係があることが確認できる。そ こで, 燃料電池とキャパシタの関係から, パレート最適解 の分布を領域に分割する。燃料電池が特に小さい解を領域 (1), キャパシタが特に小さい解を領域 (5) とする。続いて, 残りの領域について検討すると, 図 9(b), 図 9(c) からわか るように,

燃料電池やキャパシタの大小によって, 燃料電池発電電 力量 $E_{G}$ の傾向が異なることが確認できる。そこで, 残り の領域のうち, 発電電力量 $E_{G}$ が特に小さくなる付近を領 域 (3) とし, 領域 (3)よりも燃料電池が小さい解を領域 (2), 領域 (3) よりもキャパシタが小さい解を領域 (4) とした。

さらに, 領域 (2) と領域 (4) に扔いて, 機器容量と発電電 力量の関係から緑で示した領域 (2-A), (4-A) と赤で示した 領域 (2-B)，(4-B) に分類する。図 9(a) のように, パレート 最適解の分布の中で，原点寄りの境界にある解を領域 B と 


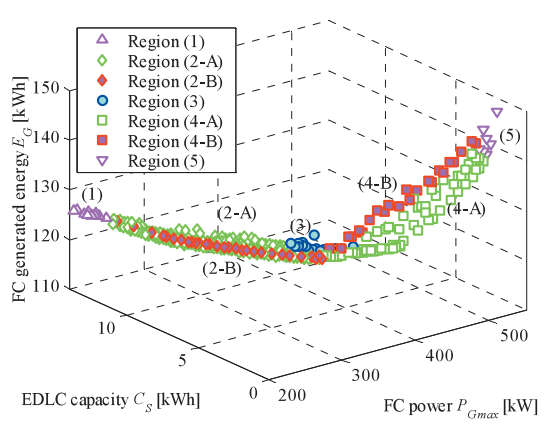

図 8 パレート最適解の分布

Fig. 8. A distribution of pareto optimal solutions.

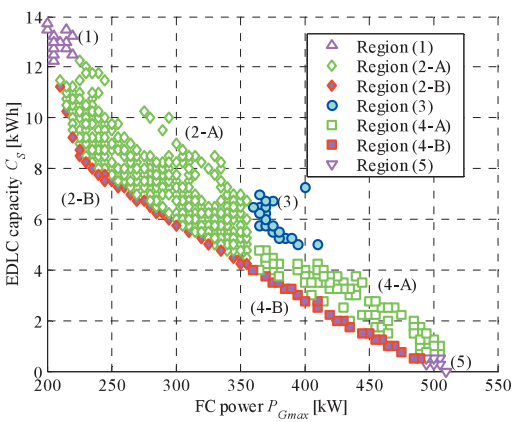

(a) 燃料電池最大出力とキャパシ夕容量の関倸

(a) Relationship between the FC power and the EDLC capacity

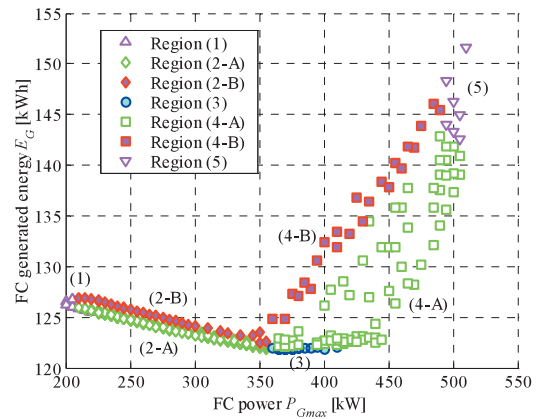

(b) 燃料電池最大出力と燃料電池発電電力量の関倸

(b) Relationship between the FC power and the FC generated energy

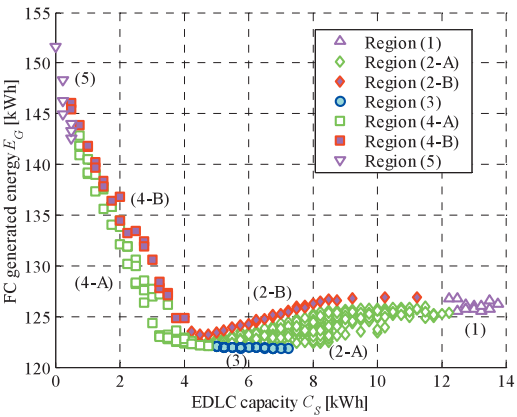

(c) キャパシタ容量と燃料電池発電電力量の関係

(c) Relationship between the EDLC capacity and the FC generated energy

図 9 パレート最適解の分布の射影

Fig. 9. Projections of a distribution of pareto optimal solutions.

する。この領域は, 機器容量を最小化するパレート最適解 である。一方, 図 9(b), 図 9(c) では, 領域 B は発電電力 量 $E_{G}$ が大きい側の境界となっている。このように領域 $\mathrm{B}$
表 4 パレート最適解の例

Table 4. Examples of pareto optimal solutions.

\begin{tabular}{r|c|r|r|r|r|r}
\hline No. & Region & $P_{G \max }[\mathrm{kW}]$ & $C_{S}[\mathrm{kWh}]$ & $E_{G}[\mathrm{kWh}]$ & $M_{h}[\mathrm{t}]$ & $E_{C}[\mathrm{kWh}]$ \\
\hline \hline 1 & $(1)$ & 200 & 13.50 & 126.64 & 3.4 & 64.5 \\
\hline 2 & $(1)$ & 210 & 13.00 & 125.90 & 3.4 & 63.2 \\
\hline 3 & $(2-\mathrm{A})$ & 250 & 9.50 & 124.70 & 3.1 & 57.3 \\
\hline 4 & $(2-\mathrm{A})$ & 300 & 7.50 & 123.31 & 3.2 & 44.2 \\
\hline 5 & $(2-\mathrm{B})$ & 250 & 7.50 & 125.78 & 2.8 & 57.7 \\
\hline 6 & $(2-\mathrm{B})$ & 300 & 5.75 & 124.14 & 2.9 & 45.1 \\
\hline 7 & $(3)$ & 370 & 6.50 & 121.93 & 3.5 & 29.2 \\
\hline 8 & $(3)$ & 400 & 7.25 & 121.87 & 3.8 & 26.9 \\
\hline 9 & $(3)$ & 410 & 5.00 & 122.08 & 3.5 & 28.7 \\
\hline 10 & $(4-\mathrm{A})$ & 400 & 4.00 & 122.45 & 3.3 & 29.2 \\
\hline 11 & $(4-\mathrm{A})$ & 450 & 2.25 & 131.93 & 3.3 & 21.7 \\
\hline 12 & $(4-\mathrm{B})$ & 400 & 2.75 & 132.47 & 3.1 & 21.5 \\
\hline 13 & $(4-\mathrm{B})$ & 450 & 1.50 & 137.82 & 3.2 & 14.3 \\
\hline 14 & $(5)$ & 500 & 0.25 & 146.21 & 3.4 & 4.8 \\
\hline 15 & $(5)$ & 510 & 0.00 & 151.61 & 3.4 & 0.0 \\
\hline
\end{tabular}

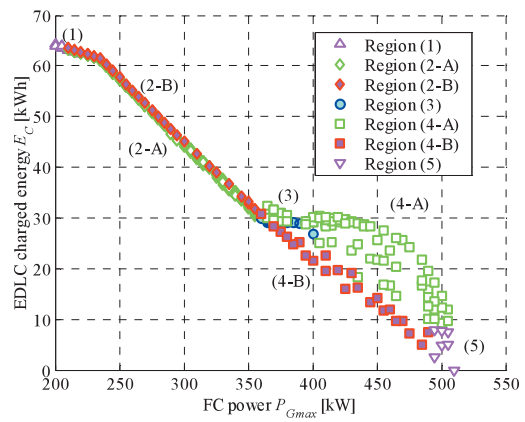

(a) 燃料電池最大出力に対する特性

(a) An FC power characteristic

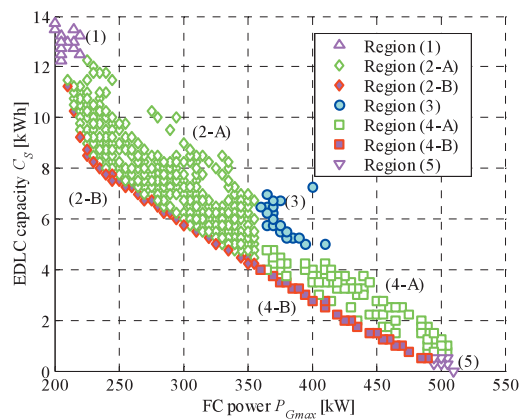

(b) キャパシ夕容量に対する特性

(b) An EDLC capacity characteristic

図 10 キャパシタの総充電電力量の特性

Fig. 10. Characteristics of EDLC charged energy.

は, 機器容量を最小化し, 発電電力量は大きくなる解とな る。逆に, 領域 A は, 機器容量には余裕があるものの, 発 電電力を小さくしている解となる。以上より, 機器容量と 発電電力量にはトレードオフ関係があることが確認できる。 以下，各領域における特徴を詳細に述べる。

領域 (1) 燃料電池が特に小さい領域図 9(a)のよう にキャパシタを最大限に大きくすることで, 燃料電池は最 小限のものを用いている領域である。特に, 表 4 の No.1 と して示した解は燃料電池が最小で, キャパシタが最大のパ レート最適解である。燃料電池の大きさを極力抑えた設計 を行う場合には，この領域の解を選択することになる。な お, この領域では, 燃料電池の出力が限られており, 必要 な電力を得るため, 走行中のほとんどの場合に燃料電池は 
最大出力で運転されている。

領域 (2) 燃料電池が小さい領域＼cjkstart燃料電池はパレート 最適解の中で比較的小さく, キャパシタは比較的大きくな る。この領域では, 燃料電池が小さくなるに従って, キャ パシタへの充放電が増え, 要求されるキャパシタが大きく なる。これにより，図 10(a)のように，燃料電池最大出力 $P_{G \max }$ が減少すると, キャパシタでの総充電電力量 $E_{C}$ は 増加する。この結果として, 然料電池が小さくなるほど, キャパシタの充放電損失と電力变換回路の変換損失が増加 し, 発電電力量は増加することが図 9(b) から確認できる。

領域 (3) 発電電力量が特に小さい領域発電電力量は 特に小さく, 領域 (2) と領域 (4) に挟まれた領域となり, 燃 料電池とキャパシタの大きさはパレート最適解の中で中間 的な值となる。その中でも発電電力量が最小となるパレー 卜最適解は, No.8の解である。省エネルギー効果を最重 視した設計を行うのであれば，この領域を選択することに なる。

領域 (4) キャパシタが小さい領域 キャパシタはパ レート最適解の中で比較的小さく，燃料電池は比較的大き くなる。この領域では, キャパシタが小さくなるほど, 回 生電力が有効に回収されず，機械ブレーキを用いる時間が 増加し, 発電電力量は増加することが図 9(c) から確認でき る。この領域では, 機器容量によって発電電力量が大きく 変わってきてしまうため, 省エネルギー効果を重視するの であれば，キャパシタの大きさに注意して設計する必要が ある。

領域 (5) キャパシタが特に小さい領域 図 9(a)のよ うに燃料電池を最大限に大きくすることで，キャパシタは 最小限のものを用いている領域である。この領域では, 回 生による省エネルギー効果がほとんど得られずに，発電電 力量は最も大きくなってしまう。特に, No.15の解は, キャ パシタが $0[\mathrm{kWh}]$, すなわち，ハイブリッド構成ではなく 燃料電池のみの車両となる。

最後に, パレート最適解の中から, 表 4 の No.3, 13 にお ける電力制御法の動作例を図 11 に示す。概ねの傾向とし ては, キャパシタ残存容量 SOCが上限付近にあるときが停 車中, 減少しているときが力行中, 増加しているときが回 生中である。燃料電池が小さいNo.3の解においては, 発 電電力 $P_{G}$ は, 多くの場合において最大出力 $P_{G \text { max }}$ である $250[\mathrm{~kW}]$ に制御されている。これに対して, 燃料電池が大 きいNo.13の解においては, SOC の状態に応じて, 発電電 力 $P_{G}$ は大きく変動している。また, この条件では, 多く の回生電力を回収する余地を残すため, 惰行時には, SOC を 35 [\%]程度に保つように制御されている。このような電 力制御法の動作例から, 多目的最適化の結果として, 機器 容量に応じて適切な電力制御法が選ばれていることが確認 できる。

これらのように, 機器容量と電力制御法を同時に考慮し たパレート最適解を分類することにより，FC-EDLC ハイ ブリッド鉄道車両の設計のための大域的な指針が明確にな

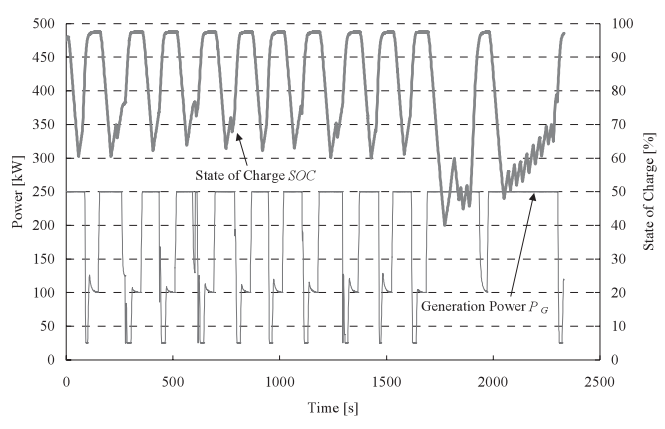

(a) No.3 (Region (2-A))

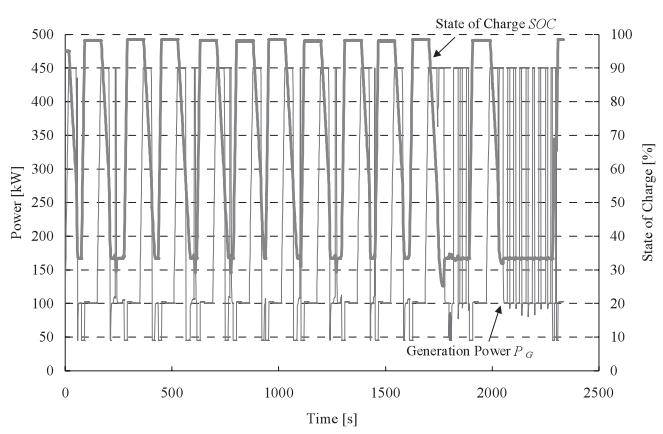

(b) No.13 (Region (4-B))

図 11 パレート最適解における電力制御法の動作例

Fig. 11. Examples of the electric power control by the pareto optimal solutions.

り，有用な知見が得られたと考えられる。

\section{5. まとめ}

本論文では，確立した設計手法の存在しない FC-EDLC ハイブリッド鉄道車両の設計において，新たに多目的最適 化設計手法を提案した。本手法では, 電力制御法を新たに モデル化した上で, 機器容量と電力制御法を同時に考慮し た多目的最適化を実施し, 広範な設計空間より有益なパレー 卜最適解を抽出する。それらのパレート最適解の分布を特 徵あるいくつかの領域に分類することで，様々な設計思想 に基づく設計パターンを容易に把握することができる。こ れは, 燃料電池とキャパシタによる FC-EDLC ハイブリッ ド鉄道車両という将来的な導入の可能性を探る基本設計段 階において，特に有用であると考えられる。

本検討では, 都市近郊を通る比較的平坦な路線を対象と した解析例を示したが，提案手法は駅間の長い路線や勾配 の多い路線など特性の異なる路線にも適用可能である。路 線特性に応じた結果の比較を今後の実施課題としたい。ま た, 本検討では, 燃料電池と電気二重層キャパシタによる FC-EDLC ハイブリッド鉄道車両を取り上げたが，その他 の種類の発電装置と蓄電装置によるハイブリッド鉄道車両 のシステム設計にも容易に展開可能であり, 今後の実施課 題としたい。

(平成 18 年 2 月 6 日受付, 平成 18 年 7 月 13 日再受付) 


\section{文献}

(1) T. Ogawa, H. Kaneko, S. Wakao, and K. Kondo: "A Study on Capacities of the Devices for a Fuel Cell Hybrid Power Railway Vehicle", The paper of Joint Technical Meeting on Transportation and Electric Railway and Linear Drives, IEE Japan, TER-05-38/LD-05-41 (2005) (in Japanese)

小川知行 ·金子晴郎·若尾真治・近藤圭一郎：「燃料電池ハイブリッ ド鉄道車両導入に向けた機器容量の検討」, 電気学会交通・電気鉄道 ノリニアドライブ合同研資, TER-05-38/LD-05-41 (2005)

(2) 電気学会: 最新 電気鉄道工学, コロナ社 (2000)

（3）松本雅行：電気鉄道, 森北出版 (1999)

(4) T. Omura, R. Shimamune, H. Nomoto, M. Shimada, T. Kaneko, and E. Toyota: "Energy Management of Hybrid Propulsion System for 'ne@train"', JIASC2004, IEE Japan, 3-3-18 (2004) (in Japanese) 大村哲朗・島宗亮平 · 野元 浩・嶋田基巳 · 金子貴志 - 豊田瑛一： 「NE トレイン用ハイブリッド動力システムのエネルギ管理」, 電学産 業応用部門大会講演論文集, 3-3-18 (2004)

(5) C.M. Fonseca and P.J. Fleming: "Genetic Algorithms for Multiobjective Optimization: Formulation, Discussion and Generalization", Genetic Algorithms: Proceedings of the Fifth International Conference, pp.416-423 (1993)

(6) Y. Collette and P. Siarry: "Multiobjective Optimization: Principles and Case Studies", Springer (2003)

小川 知 行 (学生員) 1979 年 10 月 5 日生。 2005 年 3 月早

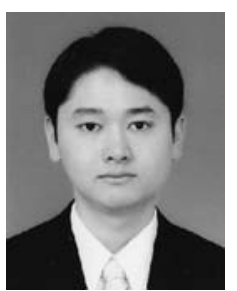
稲田大学大学院理工学研究科修士課程修了。同年 4 月同大学院博士後期課程入学, 現在に至る。主 として, 鉄道車両駆動システムに関する研究に従 事。2005 年電気学会優秀論文発表賞受賞。2006 年 IEEE PELS Japan Chapter “the Young Engineer's Best Paper of the Year Award” 受賞。IEEE 学生員。
若 尾 真 治 (正員) 1965 年 7 月 7 日生。1993 年 3 月早稲田

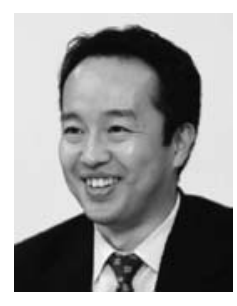
大学大学院理工学研究科博士後期課程修了。1996 年 4 月早稲田大学理工学部専任講師, 以後, 助教 授を経て, 2006 年 4 月同大学理工学術院教授, 現 在に至る。博士 (工学)。主として, 電磁エネル ギー機器を対象とする数值解析技術に関する研究 に従事。IEEE, 日本計算工学会, 日本太陽エネル ギー学会などの会員。

近 藤 圭一郎 (正員) 1968 年 11 月 10 日生。1991 年 3 月早稲

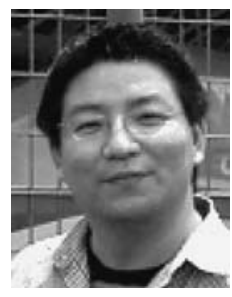
田大学理工学部電気工学科卒業, 同年 4 月, (財) 鉄道総合技術研究所入所。電気車におけるパワー エレクトロニクス, 交流電動機制御等の研究開発 に従事。現在，同所車両制御技術研究部動力シス テム研究室主任研究員。博士 (工学)。技術士 (機 械部門·総合技術監理部門)。1997，2002 年電気 学会論文発表賞受賞。2003 年電気関係学会関西 支部連合大会論文発表賞受賞。IEEE 会員。 